KS. MARIAN BRUDZISZ - KRAKÓW

\title{
ZASOBY ARCHIWALNE POLSKICH MISJI KATOLICKICH WE FRANCJI I W NIEMCZECH ORAZ KONGREGACJI DO NADZWYCZAJNYCH SPRAW KOŚCIOLA
}

Kwerenda do historii redemptorystów w Polsce i w świecie pozwoliła poznać zawartość wielu archiwów kościelnych. Wśród nich także archiwalia niektórych Polskich Misji Katolickich w Europie, przede wszystkim we Francji i w Niemczech oraz Archiwum Kongregacji do Nadzwyczajnych Spraw Kościoła, udostępnionego kilka lat temu. Moim zadaniem jest podzielenie się z zebranymi na tym sympozjum archiwistami i historykami, posiadanymi wiadomościami o stanie i zawartości wymienionych tutaj archiwów.

\section{Archiwum Polskiej Misji Katolickiej we Francji}

Do 1922 istniało w Paryżu duszpasterstwo polskie, którego początki sięgaja 1836 ${ }^{1}$, owoc działalności m. i. ks. Aleksandra Jełowickiego (1804-1877)², w 1917 zostało przekształcone w „Polską Misję Katolicką”. Aktywność tego duszpasterstwa na przełomie XIX i XX wieku znacznie osłabła, gdyż liczebność Polonii francuskiej uległa znacznej redukcji. Masowy napływ Polaków do Francji, zwłaszcza po zakończeniu pierwszej wojny światowej, zarówno z kraju jak i z Niemiec, do pracy we fabrykach, kopalniach i w rolnictwie, głównie w północnowschodnich departamentach ${ }^{3}$, na porządku dziennym postawił problem reorganizacji

${ }^{1}$ J. Klechta, Najstarsza w świecie. Polska Misja Katolicka we Francji 1836-2006, Paryż 2006, s. 40 .

2 Tenże, Powstaniec - tułacz - kapłan, ks. Aleksander Jełowicki (1804-1877), pierwszy rektor Polskiej Misji Katolickiej we Francji, Paryż 2004, s. 89-125. Przed rokiem 1922 duszpasterstwo polskie w Paryżu nazywame było „Misja Polska w Paryżu” lub „Misja Polska Paryska”, zob. Klechta, Powstaniec, s. 116-122 (Sprawozanie k. A. Jełowickiego z 1873), a nie Polska Misja Katolicka we Francji.

3 J. Rozwadowski, Emigracja polska we Francji, Lille 1927; Cz. Kaczmarek, L'émigaration polonaise en France après la guerre, [Paris 1928]; H. Janowska, Polska emigracja zarobkowa we Francji 1919-1939, Warszawa 1964; P. W. Mynarz, Społeczna działalność ks. Ferdynanda Machaya 
duszpasterstwa polskojęzycznego. Wołanie polskich imigrantów ${ }^{4}$ o polskojęzycznych duszpasterzy docierało nie tylko do właścicieli francuskich hut, fabryk, kopalni i godpodarstw rolnych, ale także do francuskich i polskich władz kościelnych. W Paryżu, przy kościele Matki Bożej Wniebowziętej, funkcjonowała „Polska Misja Katolicka", ale jej rektor, ks. Leon Postawka (1839-1923), starszy już kapłan i chory, nie był zdolny do podjęcia nowych zadań. Po rozeznaniu zaistniałej sytuacji, przedstawiciele episkopatów Francji i Polski w czerwcu 1922 utworzyli „Polską Misję Katolicką we Francji”’. Jej pierwszym rektorem 10 maja 1922 został mianowany ks. Wilhelm Szymbor (1879-1949) ${ }^{6}$, ze zgromadzenia Księży Misjonarzy, który, jako były duszpasterz wędrowny, znał problemy polskich emigrantów poza Polską, zwłaszcza w Niemczech. Pierwszy regulamin dla tego duszpasterstwa został opracowany w 1924 i ogłoszony w 1925. Dziełem rektora ks. Szymbora w latach 1922-1928 było ustanowienie licznych ośrodków duszpasterstwa polskojęzycznego. W 1930, czyli na początku rektoratu ks. Leona Lagody (1894-1942) , który obowiązki rektora pełnił w latach 1929-1933, było już 30, głównie w departamentach północno wschodnich ${ }^{8}$. W następnych latach wzrastała liczba ośrodków i punktów duszpasterskich, ale centralnym pozostaje ten przy kościele Matki Bożej Wniebowziętej, funkcjonujący jako parafia pod tym samym wezwaniem.

\section{1. Nieco historii archiwum PMK we Francji}

Duszpasterstwo, a następnie Parafia Polska w Paryżu posiadała własne archiwum, które w latach 1972 i 1973 uporządkował prof. Stanisław Litak i sporządził inwentarz. Niestety, jego dawny, cenny zasób, kilka lat temu, uległ zagładzie9 Pozostały w zasadzie tylko księgi metryk.

wśród polskiej emigracji zarobkowej we Francji (1922-1924, w: Studia Polonijne. T. 1, Lublin 1976, s. 85-89; Klechta, Najstarsza wświecie, s. 139-142, i i.

${ }^{4}$ R. Dzwonkowski, Życie religijne Polonii francuskiej w latach 1920-1986, jako wyraz więźi z krajem pochodzenia, w: Studia Polonijne, t. 15, s. 35-37 (tu dalsze informacje bibliograficzne).

${ }^{5}$ Klechta, Najstarsza w świecie, s. 142-144.

${ }^{6}$ S. Janaczek, Szymbor Wilhelm (1879-1949), w: Stownik Polskich Teologów Katolickich, t. 7 , red. L. Grzebień, Warszawa 1983, s. 272-276. Ks. Szymbor jest autorem kilkunastu artykułów o życiu religijnym Polonii francuskiej.

${ }^{7}$ M. Banaszak, Lagoda Leon (1894-1942), w: Słownik Polskich Teologów Katolickich, t. 6, s. 364-366.

${ }^{8}$ R. Dzwonkowski, Wspótpraca polsko-francuska w organizacji opieki religijnej dla Polaków we Francji 1909-1939, „Duszpasterz Polski Zagranicą”, 34 (1983) nr 1, s. 517-541; tenże, Reorganizacja Misji Polskiej w Paryżu 1919-1925, „Duszpasterz Polski Zagranicą”, 34 (1983) nr 1, s. 60 -83; B. Kołodziej, Opieka duszpasterska nad wychodźcami polskimi do roku 1939, Poznań 2003, s. 313-325.

${ }^{9}$ Archiwum Parafii Polskiej w Paryżu, zawierające cenne materiały źródłowe do historii Polonii we Francji aż do lat sześćdziesiątych wieku XX, prof. Stanisław Litak z KUL uporządkował w latach 1972 i 1973 przy pomocy polskich studentek we Francji i sporządził inwentarz. Zob. S. Litak, Materiały źródłowe do dziejów Polonii francuskiej w Archiwum Parafii Polskiej w Paryżu, w: Studia 
Polska Misja Katolicka (PMK) we Francji, wkrótce po jej ustanowieniu w 1922 rozpoczęła gromadzenie swoich dokumentów, listów, sprawozdań, akt ośrodków duszpasterskich, organizacji religijnych i cywilnych emigrantów polskich, akt personalnych itd. Inwentarz sporządzony 16 X 1933 zawierał w zespole „A”: Akta ogólne: registry korespondencji Rektoratu z lat 1929-1930 (nie wiadomo ile teczek); osobne registry korespondencji od 1931 (14 teczek); ,teki” zawierające sprawozdania $\mathrm{z}$ „Objazdów rolnych”, dokonywanych sezonowo przez „misjonarzy”, a ponadto sprawozdania ze „Zjazdów księży”. W zespole „B”: Akta specjalne, w ośmiu „małych teczkach” znajdowały się: I. Règlement des Aumôniers diecezji Cambrai i Arras; II Pielgrzymka do Kartaginy, III, Objazdy biskupa Kubiny, IV Rachunki Księgarni Popularnej, V. Wyjazdy studentów [kleryków] na wakacje do Polski, VI. Sprawy szkolne, VI. Seminarium zagraniczne, VIII. Zastępstwa w czasie wakacyjnym. W zespole „C”: Akta różne, w pudłach były: pudło I. Okólniki rektoratu, personalia księży, placówki duszpasterskie z roku 193 [? 0, 1, 2]; pudło II. Protokoły Rady Misji, protokoły zebrań księży od 1923 do 1929, sprawozdania z placówek duszpasterskich, protokoły zebrań dekanalnych, sprawozdania ze Zjazdu księży okregu paryskiego 1928-1929; pudło III. Sprawozdanie i akta placówki duszpasterskiej w Caen, sprawozdanie z Argenteuil, Regulaminy i statuty Stow[arzyszenia] Dzieci, stosunek nauczycielstwa do księży; pudło IV. Kontrakty i projekty kontraktów, umowa między proboszczem parafii Madeleine a rektorem Misji, ii. Ten najstarszy zasób jest znany, dzięki odnalezionej kopii jego inwentarza, sporządzonej w $1947 \mathrm{w}$.

W ciągu następnych lat dokumetacja PMK narastała nadzwyczajnie i w 1947 liczyła już 189 teczek, które zawierają szczegółowy wykaz ich zawartości. W związku z odejściem ks. Franciszka Cegiełki (1908-2003), rektora Misji w latach 1937-1947, do protokołu procedury zdawczo odbiorczej dołączono także aktualny, szczegółowy inwentarz archiwum, sporządzony 15 IX 1947 przez brata Władysława Szynakiewicza, chrystusowca.

W okresie rektoratu ks. Kazimierza Kwaśnego, 1947-1972, zasób archiwalny znacznie się powiększył i jego magazynowanie stawało się trudnym problemem w ciasnym lokalu Misji na rue Saint Honoré 263 bis. Opieka nad zasobem zasadniczo spoczywała w rękach sekretarza Misji, ale wiele czasu poświęcał mu brak Władysław Szynakiewicz.

Lata siedemdziesiąte ubiegłego wieku nie były łaskawe dla archiwum PMK w Paryżu. To wówczas dokonano w nim swoistego brakowania akt. Pisze o nim ks. prof. Roman Dzwonkowski: „Dla historii duszpasterstwa polskiego we Francji bardzo ważnym źródłem jest archiwum Polskiej Misji Katolickiej w Paryżu. Nie było ono dotychczas, w zasadzie, wykorzystywane dla historycznych badań na-

Polonijne. t. 1, Lublin 1978, s. 103-108. S. Litak określił wielkość tego archiwum na 6, 5 m bieżących. Jako szczególnie wartościowe wymienił on: korespondencję Polaków zamieszkałych we Francji z lat 1940-1958 (54 teczki), która często dotyczyła poszukiwania metryk; akta dotyczące działania Caritasu w stosunku do młodzieży, ludzi poszukujących środków do życia, byłych obozowiczów, z lat 1931-1962 (38 teczek); akta ludzi poszukujących pracy w latach 1946-1963 (9 teczek); akta Związku Robotników Rolnych, łącznie z jego kartoteką personalną (2863 pozycji, w 12 skrzynkach). Tych akt w Archiwum Parafii Polskiej nie ma (dane z 14 sierpnia 2007). 
ukowych. Od kilkunastu lat jednak, z polecenia rektora Misji, ks. prałata Zbigniewa S. Bernackiego, było ono dla nikogo niedostępne. Po roku 1970 została zniszczona część zawierająca źródła z okresu od drugiej połowy wieku XIX, do lat sześćdziesiątych wieku XX. Należała do niej także obszerna dokumentacja Sekretariatu Związku Robotników Rolnych, zorganizowanego przez Misję oraz protokoły z objazdów duszpasterskich biskupów polskich we Francji w okresie międzywojennym. Stanowi to stratę niepowetowaną"10.

Drugim tekstem świadczącym o usunięciu części starych akt jest notatka jednego z pracowników kurii Misji, sporządzona na kopercie, która jakoś przetrwała do dzisiaj. Oto ona: „Likwidując stare akta, wyjąłem pewne spisy mogące mieć ew. znaczenie archiwalne dla P. M. Katol. X.Z”. We wspomnianej kopercie pozostał tylko jeden wykaz duszpasterzy Misji. Szkoda, że jej autor nie sporządził szczegółowego wykazu akt, które zlikwidował. Dziś już wiadomo, że nie likwidowano wszystkich starych akt i tych do lat sześćdziesiątych wieku XX, o czym świadczy aktualny stan zasobu archiwalnego.

W związku z dokonanym brakowaniem rodzi się pytanie o jego powody. O ile piszącemu udało się należycie je poznać, to zasadniczą rolę odegrał brak miejsca, a następnie brak zrozumienia dla wartości posiadanej dokumentacji dla historii Polonii we Francji i organizowanego dla niej duszpasterstwa polskojęzycznego.

Owocem dokonanego „brakowania” i braku miejsca dla zasobu archiwalnego był najpierw częściowy, a następnie całkowity zakaz jego udostępniania, wydany przez ks. Zbigniewa Bernackiego (1920-1985), rektora PMK we Francji w latach 1972-1985. Pod koniec XX wieku archiwum przewieziono do zastępczych pomieszczeń w Domu Polskiej Misji Katolickiej w La Ferté sous Jouarre, niestety, nieprzystosowanych do wymogów takiej instytucji. Przewiezienie, wykonane przez nieodpowiedzialnych robotników, doprowadziło do kolejnej dezorganizacji archiwum. Obecnie, dzięki decyzji Księdza Infułata Stanisława Jeża, aktualnego Rektora PMK we Francji, rozpoczęły się prace mające na celu uporządkowanie i sporządzenie inwentarza.

Zaistniała sytuacja sprawiła, że w latach osiemdziesiątych dosyć obficie korzystał z niektórych zespołów o. prof. Bronisław Panek, karmelita ${ }^{11}$. Kwerendy w jego zasobach nie mógł już przeprowadzić ks. prof. Roman Dzwonkowski, jak

${ }^{10}$ R. Dzwonkowski, Polska opieka religijna we Francji 1909-1939, Poznań 1988, s. 15.

${ }^{11}$ B. Panek, Materiaty do dziejów Polskiej Misji Katolickiej we Francji, zeszyty publikowane w Paryżu i w Warszawie od 1991, dotyczące duchowieństwa polskiego pracującego dla Polonii francuskiej od 1922, m. i. Les prêtres dans la pastorale des imigrgrés Polonais en France depuis 1922, Paris 1991; La pastorale polonaise occasionelle dans le doyenné de Paris 1941-1945, Paris 1991; Księżapolscy wduszpasterstwieokręuparyskiego 1922-1929, Paris 1992; Księżapolscywduszpasterstwie poludniowej Francji 1922-1929, Paris 1993; Księża polscy w duszpasterstwie dekanatu wschodniego 1922-1929, Paris 1994. 
to sam wyznaje; nie miał takiej możliwości również ks. prof. Bernard Kołodziej ${ }^{12}$, a w bardzo ograniczonym zakresie Gabriel Garçon ${ }^{13}$.

Inwentarze z 1933 i 1947 i ten aktualnie sporządzany być może pozwolą ustalić, czego brak w obecnym zasobie archiwalnym, czy rzeczywiście wszystkie wyżej wymienione zlikwidowane akta przedpadły, czy coś z nich przekazano do archiwum PMK we Francji? Na odpowiedź na to pytanie trzeba poczekać do zakończenia inwentaryzacji.

\subsection{Aktualna zawartość archiwum PMK we Fancji, czyli od 1922}

Archiwum PMK we Francji, pomimo różnych „brakowań” i strat nadal posiada bogatą dokumentację, zasługującą na uwagę historyków. Kolejna jego inwentaryzacja, zorganizowana przez Księdza Infułata i Rektora Stanisława Jeża ma doprowadzić do udostępnienia jego liczących się zasobów. Na obecnym etapie prac inwentaryzacyjnych można wskazać tylko podstawowe tematy, do których istnieje dokumentacja, choć czasen niekompletna.

1. Władze zwierzchnie PMK we Francji: Stolica Apostolska, podstawowe dokumenty papieży, kongregacji konsystorialnej i innych urzędów rzymskich dotyczące duszpasterstwa migrantów; dokumemty (m. i. regulaminy) i korespondencja arcybiskupów Paryża oraz biskupów francuskich dla PMK, od 1924; obfita dokumentacja Komisji Duszpasterskiej Episkopatu Francji do Spraw Migracji (Commission Episcopale des Migrants, która z biegiem lat zmieniala nieco swoją nazwę), od 1954; dokumenty i korespondencja Prymasa Polski, jako Protektora Polonii w świecie, oraz korespondencja biskupów polskich, od 1927.

2. Rektorat PMK we Francji: nominacje rektora, jego uprawnienia, koordynacja pracy duszpasterskiej z władami kościelnymi Kościoła katolickiego we Francji; załatwianie spraw jurysdykcyjnych dla duszpasterzy PMK z biskupami Francji; załatwianie spraw administracyjnych i duszpasterskich z Prymasem Polski, Protektorem Polonii; kontakty ordynariuszami diecezjalnymi i zakonnymi w Polsce, związane $\mathrm{z}$ angażowaniem duchownych do pracy w PMK; obsada ośrodków duszpasterskich; dokształcanie duszpasterzy, m. i. w ramach corocznych zebrań czy doraźnie organizowanych sympozjów; organizowanie corocznych rekolekcji; korespondencja $\mathrm{w}$ wielotematyczna $\mathrm{z}$ instytucjami i konkretnymi osobami. W zakresie korepondencji szczególnym pomocnikiem jest sekretarz generalny. Dokumenty i korespondencja rektoratu Misji istnieje od 1927, dosyć obfita dla lat 19271932 i po 1945.

3. Państwowe władze francuskie, centralne i departamentalne oraz polskie (głównie ambasady i konsulaty polskie we Francji).

${ }^{12}$ B. Kołodziej, Opieka duszpasterska nad wychodźcami polskimi do roku 1939, Poznań 2003; brak archiwum PMK we Fancji, zarówno w wykazie Źródel, jak i na stronach 313-325, poświęconych duszpasterstwu we „Francji”.

${ }^{13}$ G. Garçon, Les catholiques polonais enFrance. Les années de fondation 1919-1949, Lille 2004. 
4. Emigracja polska we Francji: zatrudnienie w kopalniach, fabrykach i w rolnictwie; organizacje polskich emigrantów, cywilne i religijne; coroczne zjazdy w Osny; udział w wojnie z niemieckim okupantem, zwłaszcza w ramach ruchu opor oporu; obozy i deportowani; organizacje kombatanckie;

5. Duszpasterze Misji: rekrutacja, Seminarium Polskie w Paryżu, dokształcanie w ramach zjazdów naukowych i duszpasterskich, rekolekcje roczne; ubezpieczenia; urlopy; katalogi, ankiety personalne z lat 1945-1968 (zawierające krótkie biogramy); akta personalno-duszpasterskie dla okresu międzywojennego (6 klaserów) i dla okresu po drugiej wojnie światowej (14 klaserów).

6. Duszpasterstwo: stan religijno moralny imigrantów polskich; troska biskupów, księży i dyrektorów przedsiębiorstw francuskich, a także polskich konsulatów, o życie religijne polskich imigrantów, proszących o duszpasterzy polskich (od 1927); korespondencja duszpasterzy polskich, od roku 1929; akta poszczególnych ośrodków duszpasterskich, w wielu wypadkach zaczynające się w 1929 roku, np. Coueron od 1929 do 1987, Troyes od 1929-1978, Barlin 1929-1992, Lens 1929-1984, Oignies 1929-1984, Salaumines 1929-1986, Auby 1929-1985 - ten ośrodek długo wydawał własny „Polski Biuletyn Parafialny” (n-ry zachochwane od 1958 do 1984), Roubaix 1929-1991 ii.; „misje objazdowe” i duszpastersrwo „objazdowe”; celebracja eucharystii i sakramentów, kaznodziejstwo, katecheza; pomoce katechetyczne; organizacje religijne; sprawozdania z zebrań polskich duszpasterzy; pielgrzymki do Lourdes i innych sanktuariów; ,peregrynacja” kopii ikony MBCzęstochowskiej.

7. „Kościół Polski” w Paryżu: historia świątyni, duszpasterstwo.

8. Zgromadzenia współpracujące z MPK: Chrystusowcy, Oblaci, Palotyni, Misjonarze św. Wincentego a Paulo i inne; sercanki (pelczarki), szarytki, urszulanki, nazaretanki ii.

9. Dobroczynność: Zakład św. Kazimierza, Caritas, „Solidarność” - pomoc Polakom w czasie stanu wojennego, Polski Czerwony Krzyż (akta zdekompletowane); pomoc studentom polskim (m. i. stypendia), pomoc w znalezieniu pracy, pomoc w legalizacji pobytu; transporty do Polski (prośby i potwierdzenia oraz podziękowania).

9. Szkolnictwo polskie we Francji.

10. Korespondencja z PMK w innych krajach

11. Bank danych personalnych Polonii we Francji: metryki sakramentów chrztu i małżeństwa; zbiór pism „Ne temere”; poszukiwania członków rodzin.

12. Stowarzyszenie „Concorde” i Domy Polonijne we Francji.

13. Dzienniki korespondencji od 1927.

Warto tu wspomnieć o około 40.000 ,listów”, nadesłanych przez parafie francuskie, a pisanych przez starszych i młodych Francuzów, zawierająca protesty przeciwko wprowadzeniu stanu wojennego w Polsce. Zasadniczo są to podpisy na gotowych tekstach, ale nie brak listów oryginalnych, ozdobnych, rysowanych lub malowanych i podpisanych przez dzieci. 


\section{Archiwum Polskiej Misji Katolickiej w Niemczech.}

Polska Misja Katolicka w Niemczech początkami sięga wyzwolenia Polaków z niemieckich obozów koncentracyjnych i z innych miejsc zniewolenia, w tym także licznych duchownych, umieszczonych głównie w Dachau (761 wyzwolonyvh z tego obozu). Początek tej Misji dał papież Pius XII mianując 5 czerwca 1945 biskupa polowego Józefa Gawlinę (1892-1964) ordynariuszem Polaków wyznania rzymsko katolickiego w Niemczech, przebywających na terenie tego kraju po 1 września 1939, tworząc diecezję personalną ${ }^{14}$. Wkrótce po nominacji biskup Gawlina zaczął ustanowiać parafie personalne, a 30 lipca 1945 we Freimannie koło Monachium zorganizował kurię biskupią dla swojej diecezji na terenie Niemiec. Po trzech tygodniach, 21 sierpnia przeniósł ją do Frankfurtu-Schwanheim, a następnie, w 1953, do centrum Frankfurtu ${ }^{15}$. Niemieccy ordynariusze i kanoniści szybko i krytycznie zareagowali na powyższe decyzje, jako niemające podstaw w prawie kanonicznym.

Pierwszym wikariuszem generalnym biskupa został dachaowiec, ks.Franciszek Jedwabski (1895-1975), który urzędował tylko do 13 listopada, z powodu wyjazdu do Polski, gdzie w 1946 został mianowany poznańskim biskupem pomocniczym. Drugim został ks. Edward Lubowiecki (1902-1975), który po śmierci biskupa Gawliny otrzymał nominację na ordynariusza Polaków katolików w Niemczech, ale bez sakry biskupiej ${ }^{16}$. Po jego śmierci diecezja personalna dla Polaków katolików w Niemczech została zniesiona, a na jej miejsce ustanowiono w 1975 Polską Misję Katolicką w Niemczech, zależną od episkopatu niemieckiego. Jej pierwszym Rektorem, za zgodą Konferencji Episkopatu Niemiec, Prymas Polski Ks. Kard. Stefan Wyszyński w 21 maja 1976 r. mianował ks. Stefana Leciejewskiego (1908-1990), który w 1977 siedzibę Misji przeniósł do Freisingu, na północ od Monachium ${ }^{17}$. Drugi Rektor Misji, ks. dr Franciszek Mrowiec (1941-), jej siedzibę w 1988 przeniósł do Würzburga, a aktualny Rektor Misji (od 2002), ks. prałat Stanisław Budyń, pod koniec 2002 do Hannoweru.

W kurii Diecezji dla Polaków w Niemczech, funkcjonującej bardzo sprawnie pod kierownictwem wikariusza generalnego księdza Lubowieckiego, oprócz innych agend istniało od początku archiwum. Jego pierwszym kierownikiem był ks.

${ }^{14}$ A. Nadolny, Organizacja duszpasterstwa polskiego na terenie Niemiec Zachodnich 1945-1975, w: Studia Polonijne, t. 2, Lublin 1978, s. 279-282, 284-294; K. Kosicki, Duszpasterstwo wśród Polaków w Niemczech w latach 1945-1950, Lublin 1993, s. 90-95; S. Bober, Duszpasterstwo polskie w Niemczech, w: Duszpasterswto polskojęzyczne w Niemczech 1945-2005 (Polnischsprachige Seelsorge in Deutschland 1945-2005), Lublin-Hannover 2006, s. 44-55; taż; Duszpasterstwo polskich robotników przymusowych $w$ Niemczech $w$ czasie i po II drugiej wojnie światowej, w: Studia polonijne. T. 28, Lublin 2006, s. 108-110.

${ }^{15}$ A. Nadolny, Organizacja duszpasterstwa polskiego na terenie Niemiec Zachodnich 19451975, s. 290; Kosicki, Duszpasterstwo wśród Polaków, s. 95-95, 114.

${ }^{16}$ A. Nadolny, Organizacja duszpasterstwa polskiego na terenie Niemiec Zachodnich 19451975, w: Studia Polonijne. t. 2, Lublin 1978, s. 305, Załącznik III.

${ }^{17}$ A. Nadolny, Organizacja duszpasterstwa polskiego na terenie Niemiec Zachodnich 19451975, s. 288. 
Edward Skowroński, a następcą ks. Zygmunt Pituła ${ }^{18}$. Wraz z kurią Polskiej Diecezji Personalnej, a od 1975 wraz kurią Polskiej Misji Katolickiej (PMK) w Niemczech, wędrowało także jej archiwum, które aktualnie w Hannowerze posiada dobry lokal. Troskliwy jego opiekum, Rektor Misji, ks. Stanisław Budyń, przygotowuje skanowanie wielkiego zespołu metryk. Do tej dokumentacji sięgało już wielu historyków, na przykład ks. dr Kazimierz Kosickii ${ }^{19}$, ks. prof. Anastazy Nadolny $^{20}$, czy dr Sabina Bober ${ }^{21}$.

Ponieważ archiwum jest jeszcze w stadium inwentaryzacji, dobrą informacją o zasobie i pomocą w korzystaniu z niego służą nie tylko robocze inwentarze, ale także personel kurii Misji. Aktualnie jego dokumentacja jest podzielona jest na trzy serie. Dwie pierwsze dotychczas były nazywane „obozami”. Pierwsza z nich otrzymuje nazwę: „Metryki”. Jej zasób, to niezwykły bank danych osobowych, obejmujący Polaków urodzonych, ochrzczonych, zaślubionych i zmarłych w poprzednim wieku w Niemczech, zwłaszcza od czasu drugiej wojny światowej. Drugą serię także nazywano „obozami”, zapewne, dlatego, że większość zawartej $\mathrm{w}$ niej dokumentacji stanowią sprawozdania z pracy duszpasterskiej w parafiach personalnych organizowanych od czerwca 1945 dla tak zwanych „dipisów” (Displaced Persons), czyli ludzi przymusowo przez władze hitlerowskie przesiedlonych z kraju rodzinnego do Niemiec. Byli to mieszkańcy tymczasowych obozów, tworzonych przez zachodnich aliantów na terenie okupowanych Niemiec po zakończeniu działań wojennych dla wszelakich „przesiedleńców”, będących owocem represji rządów hitlerowskich w okupowanych krajach. Zarówno określenie „obozy”, jak i „parafie” czy „ośrodki duszpasterskie”), nie jest adekwatne do zawartości tej serii, dlatego aktualnie, ,roboczo”, nosi nazwę „Ośrodki duszpasterskie".

Pierwsza seria: „Metryki”, licząca ponad 460 tek numerowanych, posiada katalog kartkowy miejscowości, w których istniały ośrodki duszpasterskie, ułożony nie zawsze alfabetycznie, stąd, trzeba go starannie przeglądać. W tej serii znajdują się księgi chrztów, małżeństw, zgonów, protokołów przedślubnych w poszczególnych ośrodkach, a także wykazy konwertytów. Kwerenda w tym „banku” jest częsta i trudna, stąd przygotowywane przez księdza Rektora Stanisława Jeża skanowanie i komputerowe opracowanie danych będzie niezwykle cenną pomoca także dla genealogów. Studium zapisów w księgach metryk treści jest bardzo in-

${ }^{18}$ A. Nadolny, Organizacja duszpasterstwa polskiego na terenie Niemiec Zachodnich 19451975, s. 291-192.

${ }^{19}$ K. Kosicki, Duszpasterstwo wśród Polaków w Niemczech w latach 1945-1950, Lublin 1993; tenże, Dzieje duszpasterstwa polskiego w Niemczech (1945-1986), w: Dodatek do „Naszego Słowa” $2006 \mathrm{Nr} 3(365)$, [16 S].

20 A. Nadolny, Organizacja duszpasterstwa polskiego na terenie Niemiec Zachodnich 19451975, w: Studia Polonijne. T. 2, Lublin 1978, s. 279-306; tenże, Opieka duszpasterska nad dziećmi i młodzieża polskq na terenie Niemiec Zachodnich w latach 1945-1965, Lublin 1980; tenże, Z dziejów polskiego duszpasterstwa na terenie Niemiec Zachodnich po II wojnie światowej. Duszpasterstwo akademickie, „Studia Pelplińskie” 8 (1977), s. 345-353.

${ }^{21}$ S. Bober, Duszpasterstwo polskich robotników przymusowych $w$ Niemczech $w$ czasie i po II wojnie światowej, w: Studia Polonijne, T. 27, Lublin 2006, s. 103-119. 
teresujące także dla liczebności i zaangażowania religijnego w ,polskich parafiach”. Przykładem może tu być zeszyt „Księga konwertytów”, znajdujący się w tece nr.18 (Augsburg), w którym pod data 6 lipca 1945 zanotowano 7 konwersji, pod datą 7 lipca 1945 - 7 konwersji, a pod datą 11 lipca - 6 konwersji. Jeszcze ciekawsze są wpisy w księgach małżeństw, dokonane w pierwszych miesiącach 1945, a więc w miesiącach czerwcu, lipcu i następnych. W moim artykule: Dusz-

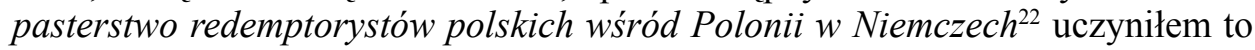
dla Augsburga i Landshutu. W Landshucie ks. Jan Gerulaitis (Litwin ?) 6 czerwca 1945 przewodniczył 27 zawieranym małżeństwom, a 9 czerwca tego samego roku pobłogosławił 10 par małżeńskich. W Augsburgu od 28 czerwca do 27 lipca 1945, a więc w ciagu jednego miesiąca pobłogosławiono 158 par, a do końca tego roku aż 237 par zawarło mażeństwo katolickie. Zawieranie małżeństw niejednokrotnie było poważnie utrudnione skutkiem braku dokumentacji i trzeba było ją uzupełniać zeznaniami. W ośrodku duszpasterskim w Augsburgu za okres od czerwca do grudnia 1945 było 237 zeznań ${ }^{23}$.

W tej interesującej serii znajduje się kilka tek, które czekają na wyłączenie z niej. Są to n-ry: 147, 172, 313, 321, 322, 323, 329, 331, 332, 336, 337 (prasa), 343 (PCK), 457-458 (prasa), 459-461 (Kuria), gdyż nie zawierają metryk. Historyka mogą spotkać miłe niespodzianki, gdyż w niektórych tekach znajdują się interesujące kroniki, jak np. w tece 104, w której, jako część V (po metrykach), znajduje się kronika: „Parafia Polska we Freimannie”, pisana przez ks. Stefana Leciejewskiego, późniejszego rektora PMK w Niemczech, lub „Kronika Rzym. Katol. Placówki w Heilbronn-Priesterwald od 26. 6. 1945 do 1.3.1948”, pisana przez ks. Henryka Malaka ${ }^{24}$. Najstarsze roczniki „Słowa Polskiego” z lat 19451946 znajdują się w tece 96A.

Seria druga liczy aktualnie ponad 370 i zawiera dokumentancję bardzo zróżnicowana, wielotematyczną. Kwerendę w tej serii ułatwia Indeks tematyczny umieszczony w tece nr 80. Mimo że jest zbyt ogólny, pomaga dotrzeć do odpowiednich tek. W tej serii historyk znajdzie materiały m. i. do następujących tematów:

1. Oblicze społeczne, psychiczne, zdrowotne i religijno moralne „dispisów”, którzy po zakończeniu drugiej wojny światowej znaleźli się w ,obozach przejściowych” lub na kwaterach prywatnych; emigracja „,solidarnościowa” i ostatnia, zarobkowa - ,ekonomiczna”.

2. Działaność organizacyjna i duszpasterska arcybiskupa Jóżefa Gawliny, ordynariusza diecezji personalnej dla Polaków w Niemczech, 1945-1964.

3. Działalność księdza prałata Edwarda Lubowieckiego, Wizytatora Kanonicznego i ordynariusza dla Polaków w Niemczech, 1964-1975.

4. Działalność Rektorów Polskiej Misji Katolickiej w Niemczech, od 1975.

5. Akta dziekanów, od 1945.

${ }^{22}$ Studia Polonijne. T. 27, Lublin 2006, s. 74, 83.

${ }^{23}$ Archiwum Polskiej Misji Katolickiej w Niemczech (Hannower), Metryki, teka 19.

${ }^{24}$ Ka. Henryk M. Malak jest także autorem dzieła Klechy w obozach śmierci, którego 3 wydanie ukazało się w wydawnictwie RETRO, Lublin - Motycz - Józefin 2004 
6. Działaność ośrodków duszpasterskich („misji”): sprawozdania dotyczące sprawowania liturgii mszalnej i sakramentalnej, nabożeństw poza liturgicznych, kaznodziejstwa, katechezy, wizyt duszpasterskich, misji i rekolekcji parafialnych, konwersji; kółka ministrantów i chóry kościelne; duszpasterstwo szkolne i akademickie; duszpasterstwo chorych, więźniów, osób przebywających w obozach dla internowanych i w kompaniach wartowniczych; pielgrzymki do sanktuarium Matki Bożej w Neviges i do innych jej sanktuariów; peregrynacja ikony MB Częstochowskiej.

7. Spisy i katalogi duchownych, statystyki. Na szczególną uwagę zasługuja teki nr 109 i 110. W tece nr 109 znajdują się wykazy: kapłanów, którzy po wyzwoleniu zgłosili się do duszpasterstwa dla dispisów na terenie Niemiec; kapłanów, którzy zgłosili się na wyjazd do Stanów Zjednoczonych, do Francji, do Brazylii, do Argentyny i innych krajów; wykaz kandydatów na studia w Rzymie. W tece nr 110 znajduje się rodzaj ankiety personalnej, zatytułowanej Podania księży o legitymację kapłańska. Większość podań zawiera skondensowane biogramy. Ponadto w tece 110 znajdziemy: Polnische Geistliche in Dachau"; Księża polscy, którzy pacuja lub pracowali w Polskich Ośrodkach strefy brytyjskiej w Niemczech, stan z 2. I. 1947; Spis kapelanów wojskowych w 1946 i 1947; statystyki za lata 19471952 znajdują się m. i. w tekach 288-290; Index 1996 sacerdotum Polonorum a Germanis AA. 1939-1945 occisorum. Wymieniony Index, opublikowany w 1953 roku, jest fragmentem pracy o. Władysława Szołdrskiego Martyrologium cleri Poloni 1939-1945, przygotowanej już druku, wówczas jeszcze nieopublikowanej $\mathrm{z}$ braku zgody cenzury.

8. Zakony współpracujące z PMK.

9. Organizacje religijne i cywilne.

10. Szkolnictw podstawowe, średnie i zawodowe.

11. Caritas.

12. Wydawnictwa oraz prasa religijna i cywilna; biblioteki,

Trzecią serię, bardzo liczną, stanowią klasery akt zmarłych, które także mają być skanowane, podobnie jak seria pierwsza.

Szczególnie bogata i cenna dokumentacja dotyczy pierwszych lat pookupacyjnych, czyli 1945-1950. Po roku 1950, w zasadzie w wyniku zakończenia emigracji polskich dipisów, maleje liczba parafii/ośrodków dla nich ustanowionych, a żywotność pozostałych słabnie. Księgi metryk są tego namacalnym dowodem. Dopiero imigracja solidarnościowa ożywia aktywność istniejących ośrodków, owszem przyczynia się do tworzenia nowych. To samo zjawisko powoduje ostatnia, ekonomiczna emigracja z kraju. Odbicie tych fal imigracyjnych widoczne jest w narastaniu akt Rektoratu PMK w Niemczech, podobnie jak we Francji.

Aby zdać sobie sprawę, jaką „kopalnią” informacji o życiu religijnym, społecznym i działałności oświatowej duszpasterzy wśród dipisów polskich w Niemczech w pierwszych latach po wyzwoleniu, trzeba studiować sprawozdania ówczesnych duszpasterzy, nadsyłane do Kurii Diecezji Personalnej w Niemczech, początkowo do Freimannu k. Monachiu, następnie do Frankfurtu n. Menem. Można na przykład przeczytać sprawozdania ks. Stefana Leciejewskiego, proboszcza 
we Freimann k. Monachium (25 IX 1945), ks. Ćwiklika, wikariusza, a następnie proboszcza w Monachium (z 19 X 45 i 25 II 46, Ośrodki teka 286), o. Jana Szymaszka, proboszcza w Augsburgu za rok 1945 (3 I 1946, Ośrodki, teka 227) czy o. Wacława Pilarczyka, duszpasterza Unterfahlheim koło Augsburga, redemptorysty (10 IX 1945 i 15 X 1945, 31 XII 1945, Ośrodki teka 227).

\section{Archivio della Congregazione degli Affari Ecclesiastici Straordinari.}

Początki Kongregacji [do] Nadzwyczajnych Spraw Kościoła sięgają roku 1793, w którym Pius VI powołał Kongregację dla Spraw Kościelnych w Królestwie Francuskim, a Pius VII w roku 1801 przekształcił ją w Kongregację do Nadzwyczajnych Spraw Kościoła. Ta Kongregacja wspierała Sekretariat Stanu w rozwiązywaniu bardziej skomplikowanych problemów, głównie na styku państwo - Kościół, względnie Kościół katolicki - inne Kościoły chrześcijańskie. Chociaż w 1967 jej miejsce zajął Urząd Międzynarodowych Spraw Kościelnych (Sacrum Consilium pro Publicis Ecclesiae Negotiis) ${ }^{25}$, któremu nadal przewodzi prefekt Sekretariatu Stanu, to jednak w Archiwum Watykańskim dla akt byłej Kongregacji zachowano pierwotną nazwę i przy zamawianiu trzeba się posługiwać siglami: A. E. S. Jej dokumentacja jest dostępna do roku 1939, do daty śmierci Piusa XI, czyli do10 II 1939. Początkowo udostępniano ją w małej czytelni, trudniej dostępnej i mało znanej, gdzie autor spotykał tylko kilka osób.

Zasób archiwalny tego archiwum posiada dwie podstawowe serie: Posizioni i Sessioni, a ponadto Carte. W skład pierwszej, Posizioni - Sprawy, wchodzą liczne zespoły, w krórych gromadzono dokumentację konkretnych problemów, pojawiających się w poszczególnych krajach świata, jaka napływała od nucjusza i innych osób do Sekretarza Stanu. Zespół każdego kraju posiada własną numerację akt. Natomiast seria Sessioni - Sesje, była wspólna dla wszystkich krajów, w kórej gromadzono dokumentację trudniejszych problemów. Studiowano je na specjalnych posiedzeniach, czyli sesjach urzędników Kongregacji oraz zaproszonych ekspertów i podejmowano decyzje.

We wszystkich seriach znajduje się bogata dokumentacja dotycząca położenia Kościoła w tych krajach, w których istniał Kościół katolicki. Problematyka Kościoła katolickiego w Polsce rozbiorowej znajduje się we wszystkich seriach, a w serii Posizioni w zespołach noszących nazwę tych państw, które uczestniczyły w rozbiorach. Zespoły nas tu interesujace, to: Russia - Polonia, Prussia-Polonia i Austria - Polonia. W 1905 pojawił się zespół Polonia, chociaż niepodległej Polski jeszcze nie było, poświęcony problematyce kościelnej głównie w Królestwie Kongresowym.

Kluczem do zawartości tych serii jest szczegółowy inwentarz, liczący ponad 30 tomów. Dokumentacja dotycząca Polski jest zawarta w kilku tomach inwentarza, z których autor wybrał tylko niektóre problemy. W zespołach Russia-Polonia i Polonia, pomijając prawie zupełnie okres powstań, został wyeksponowany

\footnotetext{
${ }^{25}$ E. Sztafrowski, Kuria rzymska, Warszawa 1981, s. 40-42.
} 
przede wszystkim koniec XIX i początek XX wieku, w granicach całego imperium rosyjskiego, aż do Władywostoku.

Dokumentacja zespołu Russia - Polonia zawarta jest w ponad 1000 pozycjach i zaczyna się od końca XVII, a kończy ze śmiercią Piusa XI. Sessioni-Sesje są również bardzo liczne, gdyż od 1814 do 1938 odbyło się ich 1389.

Wybrane problemy w zespole Russia - Polonia.

Szczególnie interesująca jest Posizio 7 (fascicolo 2): Relazione di Mons. Lorenzo Litta, Arcivescovo di Tebe, sopra diversi Affari Ecclesiastici da lui trattati, come Nunzio Apostolico in Polonia e come Ambasciatore di PP. Pio VI alla Corte Imperiale di Russia, sporządzona w 1800 (?).

Na początku pisze o zdradzie biskupa W. Skarszewskiego, którego on, jako nuncjusz, udając się poza Warszawę, do Kościuszki, ratuje od wykonania wyroku śmierci; po tej informacji następuje obszerne, w dziewięciu artykułach, omówienie stanu Kościoła katolickiego w Rosji i Prusach po trzecim rozbiorze: artykuł I. Stan Kościoła katolickiego po śmierci Katarzyny II, na ziemiach przez nia Polsce zabranych, artykuł II. Wynik pertraktacji z dworem rosyjskim, artykuł III. Organizacja hierarchii łacińskiej w Rosji, artykuł IV. Organizacja hierachii unickiej w Rosji, artykuł V. Wytyczne Stolicy Apostolskiej, co do władzy biskupów nad zakonami, artykuł VI. Sugestia stworzenia przedstawicielstwa Stolicy Apostoskiej przy rządzie rosyjskim, artykuł VII. Dyspozycje, co do jego funkcjonowania, artykuł VIII. Opinie o biskupach katolickich w Rosji, zwłaszcza o Siestrzeńczewiczu, artykuł IX. Sytuacji Kościoła w zaborze pruskim po zajęciu Warszawy przez Prusy w 1796, przymusowa rezygnacja W. Litty ze stanowiska nuncjusza i przekazanie jego funkcji Janowi Albertrandi, biskupowi pomocniczemu poznańskiemu w 1797, a w 1799 przedłużone na następne trzy lata.

Posizioni 13+16+20 - raport abp. Raczyńskiego 1807 i analizy kongregacji; posizio 47 - relacja ks. Zajączkowskiego, misjonarza z 1830 oraz audytora nuncjatury wiedeńskiej z 1831; posizio 62 - raport nuncjusza wiedeńskiego Ostini o sytuacji Kościoła w Królestwie w 1833; posizio 69 - stan Kościoła katolickiego na ziemiach zabranych przez Rosję, 1834; posizio 440 - wykaz kleru i zakoników zamordowanych lub torturowanych w Rosji, 1879; posizio 453 - relacja bp. W. Popiela o stanie Kościoła w Królestwie i w Rosji, 1879; posizioni 456, 497, 500, 559, 561, 596, 621, 659, 735 - Stan Kościoła unickiego w Ziemi Chełmskiej i na Podlasiu, prześladowanie unitów, tajne misje jezuitów (M. Mycielski i Henryk Jackowski), 1880-1882, 1884; posizio 478 - relacja bp. W. Popiela, 1888-1881; posizio 483 - przygotowania Watykanu do „rozmów” z caratem o sytuacji Kościoła katolickiego w Rosji, 1881; posizio 487 - wykaz biskupów, księży i zakonników zesłanych na Syberię, 1881; posizio 488 - Memorandum narodu polskiego do Leona XIII w związku z powyższymi „rozmowami” 1881; posizio 490 - Sprawozdanie z powyższych „rozmów”; posizio 496 - relacja hr. księdza J. Szembeka o stanie Kościoła katolickiego w diecezjach imperium rosyjskiego, 1881-1882; posizio 587 - Coup d'oeil sur la sutuation de l'Eglise catholique en Pologne. Memoria presentata ... a Parigi dal Conte Ladislas Plater, 1886; posizio 594 - prześladowanie Kościoła w Rosji i Polsce, raport kard. Mieczysława Ledóchowskiego i Kazimierza Skirmunta, 1886-1887; posizio 645 - prześladowanie Kościoła 
w Rosji, 1888; posizio 701 - rosyjskie antykościelne prawodawstwo w latach 1857-1893; posizio 709 - Memorandum ks. St. Stojałowskiego w sprawie prześladowania Kościoła katolickiego w Rosji, 1894; posizio 848 - instrukcje dla generał gubernatora Czertkowa w odniesieniu do Kościoła i kleru katolickiego w Rosji i Królestwie, 1901; posizio 882 - kandydaci na arcybiskupstwo warszawskie, 1901-1916.; posizio 887 - kandydaci na biskupów, 1903-1908; posizio 906 - ukaz tolerancyjny i inne dokumenty, także o sytuacji zakonów (m.i. redemptorystów), 1905-1912; posizio 907 - sytuacja Kościoła w Rosji i Królestwie, mariawici, redemptoryści, Kościół we Finlandii, różne relacje, bardzo interesujące, dokument bardzo obszerny, obejmujący lata 1905-1913; posizio 908 - informacje o kilku diecezjach, relacje prałatów Skirmunta i Sapiehy, 1905-1914); posizio 935 - stan Kościoła w latach 1913-1919); posizio 47 (i „Carte di R. e Pol.”, vol IV) - panorama Kościoła prawosławnego w Rosji w 1830; plan przeniesienia stolicy metropolitalnej z Mohylewa do Wilna, zakony; posizio 440 - wykaz zamordowanych kapłanów i zakoników; posizioni 456, 497, 500, 549 (i dalsze) - sytuacja Kościoła unickiego, tajne misje na Podlasiu i w Chełmszczyźnie (o. Jackowski), specjalne władze dla o. prow. Mycielskiego, lata 1878-1882, 1884); posizio 497 i 500 (lata 1881-1882); posizioni 581, 593, 680, 685, 693, 700, 712, 722, 750, 772, 805, $809,857,872,881$ - ingerencja rządu rosyjskiego we funkcjonowanie seminariów duchownych, lata 1885-1903; posizio 618 (i inne) -narzucanie języka rosyjskiego w nabożeństwach paraliturgicznych, 1888; posizioni 647, 663, 721, 734, 754, 820, 912 - katolicy na Syberii; posizio 997 - Kościół unicki w Galicji, 19181921; posizio 999 - redemptoryści obrządku wschodniego w Galicji, 1919.

W zespole „Polonia” spotkamy m.i. następujące tematy: posizio 11 - mariawici, projekt kongregacji, 1904; posizio 23 - „kongres” biskupów warszawskiej prowincji; posizio 27 - Stan polityczno religijny Królestwa Polskiego (raport hr, J. Ostrowskiego 1907); posizio 23 - seminaria, program nauczania, egzaminy z j. ros., literatury i historii Rosji, 1907; posizioni 27 i 31 - demokracja chrześcijańska, chrześcijańskie stowarzyszenie robotników i moderniści, 1908 (Polskie Stowarzyszenie Katolickie; „Nowy sztandar”); posizio 92 - kwestia polsko ukraińska, 1921 (m.i. artykuły prasowe oraz tajne spotkanie członków Partii Komunistów Galicji Wschodniej i delegata Komitetu Centralnego Partii Komunistycznej Robotników Polskich, w szkole przyległej do kościoła św. Jura).

$\mathrm{Na}$ uwagę zasługują również tematy dyskutowane na sesjach Kongregacji do Nadzwyczajnych Spraw Kościoła. Oto niektóre z nich: sesja 109 - obsadzanie stolicy arcybiskupiej w Mohylewie po śmierci Siestrzeńczewicza; sesja 276 - bulla cykumskrypcyjna dla diecezji łacińskich w Rosji, 1848; sesje 207, 275B, 280, 294, 382, 384, $957+1084+1097,1105,1107$ - obsadzanie stolic biskupich, kandydaci, usuwanie biskupów, (207 - m. i. usunięcie bp. J. M. Gutkowskiego, 957, 1084, 1097, 1107 - usunięcie bp. roppa z Wilna); sesje 113, 202, 233, 1108+1117+1126 - sytuacja Kościoła unickiego, jego likwidacja przez władze carskie, tajne misje jezuitów na Chełmszczyźnie, sytuacja po ukazie tolerancyjnym; sesja 194 - projekt przeniesienia siedziby metropolii mohylewskiej do Wilna, 1838; sesja 261 - zakony, 1847; sesje 263, 264, 265, 267, 270, 275B, 276, 277 - dyskusje i decyzje konkordatowe Rosji i Watykanu, 1847-1848; sesja 372 - ukaz 
carski ustanawiający Komisje Kultu i Oświaty dla Królestwa Polskiego w 1862; sesje 382, 384, 387 ii. - represje po powstaniu styczniowym; sesje 1075 i 1084 język rosyjski w nabożeństwach; sesje 389 i 395 - Austria zrywa konkordat, 18681870; sesje 394, 397..., 803, 962, 1052, 1088 - walka Prus z Kościołem katolickim od 1869 do 1907; sesje 719, 761, 780, 834, 856, 999 - carska kontrola seminariów duchownych i nauczanie języka rosyjskiego, 1893-1903; sesje 747, 748 kwestia społeczna w Austrii w 1895; sesja 1084 - konferencja biskupów w Wareszawie, 1907.

\section{Zakończenie}

Podjęty temat został omówiony bardzo zwięźle. Zadecydowały o tym ramy odczytu-artykułu, stan archiwów i racje formalne. Dokumentacja dotycząca Polonii we Francji i w Niemczech nie jest jeszcze w pełni zinwentaryzowana, a więc mogą pojawić się nowe materiały i nowe tematy, zaslugujące na ich podjęcie przez historyków. Natomiast zasób archiwalny Kongregacji do Nadzwyczajnych Spraw Kościoła jest dobrze opracowany w około czterdziestu tomach inwentarza. Inwentarz serii „posizioni” i sessioni”, które dotyczą Kościoła w Polsce w okresie rozbiorów i po odzyskaniu niepodległości, wypełnia kilka tomów. Z racji formalnych można było podzielić się tylko wybranymi ich fragmentami inwentarza. Dostęp do zasobu tego archiwum kończy się na aktach pontyfikatu Piusa XI, wraz ze śmiercią tego papieża 10 II 1939 roku. 